\title{
汎用型分光蛍光光度計を用いる固体蛍光体の絶対蛍光量子 収率測定を可能にする簡易補正方法
}

\author{
堀 込 純 $^{\circledR 1}$, 和久井隆行 ${ }^{1}$, 白崎 俊浩 $^{1}$
}

\begin{abstract}
一般的な分光蛍光光度計に積分球を搭載したシステムにて, 絶対法による固体試料の蛍光量子収率測定方 法の検討を行った，特に，積分球を搭載した際に生じる波長特性を補正するために，分光蛍光光度計に搭載 されている励起光源を用いて, 光拡散素子と積分球の波長特性を比演算する補正方法を検討した. この結果, 波長 $200 \sim 800 \mathrm{~nm}$ までの補正スペクトル取得を可能とした。この補正方法を用いた蛍光量子収率の測定に おいては，報告值のある $\mathrm{MgWO}_{4}$ の測定を行ったところ，蛍光量子収率は $0.80 （$ 相対標準偏差 $0.6 \%$ ）と報 告值の 0.81 とほほ一致した結果が得られた。
\end{abstract}

\section{1 緒言}

近年，デイスプレイや白色発光ダイオード（LED）光源 の省エネルギー化に向けて，それに使用される蛍光体の高 効率化への取り組みが盛んに行われている。 これらの蛍光 体の発光効率評価には, 固体状態での蛍光量子収率の測定 が有用とされ，実際に利用されつつある。

固体試料の蛍光量子収率を測定する際の留意点として は, 蛍光量子収率が既知の標準蛍光物質が知られていない ため，一般に測定されている相対法を用いることができ ず，絶対法により蛍光量子収率を算出しなくてはならな い. また, 固体試料の場合, 蛍光は表面測光のため, それ ぞれの試料により発する蛍光の方向依存性があり, それら の蛍光を集めるために積分球を必要とする．また，分光蛍 光光度計による蛍光スペクトルの測定は, 測定システム由 来 (光源, 分光器, 積分球, ホトマルなど) の装置固有の 波長特性を有するので装置関数を取得し，スペクトルの補 正が必要である。これらのことから積分球を用いたスペク トル補正の確立が有用と考えられるが，積分球を含めた補 正の方法は, 報告例が少ない.

積分球を含めた補正方法として，大久保ら ${ }^{1)}$ がコーン型 放射検出器を用いた方法を報告している。 この方法は試料 に照射される励起光の波長特性を取得する際にはコーン型 放射検出器を用い, 量子収率測定の際には分光測定検出器 を用いる，それぞれの検知器を交換するには，ファイバー 入力の光学系では可能であるが, 一般的な分光蛍光光度計 においては光軸などの再調整が生じるので適用することは 難しい. また, 分光出力特性が求められている副標準光源

${ }^{1}$ 株式会社日立ハイテクノロジーズ : 312-0057 茨城県ひたちな か市石川町 11-1
にて積分球を含めた波長特性を補正する方法2)3) では, 副標 準光源の值付けされている波長域のみに測定波長が限定さ れてしまう．副標準光源として一般的に用いられているハ ロゲンランプは, 特に補正が必要である紫外域での放射強 度が少なく，更には積分球の内面材料の吸収が顕著なた め, 光拡散効率が低下し検知する光量は非常に少なくな る. そのため, この標準光源を用いる補正方法では，紫外 域での補正の誤差は大きい，また，実際測定に使用する光 源と標準光源は, 光を導入する光学系やランプのプロファ イルが異なることも誤差要因となる.

そこで, 本報告では, 測定波長全域（波長 $200 ８ 00 \mathrm{~nm}$ ) にわたり積分球の波長特性の補正を容易に可能とするため に，分光蛍光光度計に搭載されている励起光源を使用する 補正方法を検討した．検討して得られた補正係数を用い， 量子収率の測定值が報告されている蛍光体を測定すること で, 補正方法と測定系の妥当性を確認した.

$$
2 \text { 実験 }
$$

\section{$2 \cdot 1$ 実験装置}

分光蛍光光度計は, 日立ハイテクノロジーズ製 F-7000 形 分光蛍光光度計を用いた．装置構成を Fig. 1 に示す．励起 光源は, ウシオ電機製 $150 \mathrm{~W}$ キセノンランプ, 検出器には 浜松ホトニクス製 R928F ホトマルを用いた，本装置は，励 起光源の変動による検出值のドリフト補正用にモニ夕検知 器を有している，通常行われる装置本体のスペクトル補正 は，励起側・蛍光側ともに波長 $200 \sim 800 \mathrm{~nm}$ である．励 起光源及び検知器の補正は, 波長 $200 \sim 500 \mathrm{~nm}$ までを口 ーダミン B 法により行い, 波長 $500 \sim 800 \mathrm{~nm}$ は副標準光 源を用いた方法を適用している(4) 6). 積分球は，外径 60 $\mathrm{mm} \phi$, 内壁を $\mathrm{BaSO}_{4}$ 塗布されているものを用いた. 4 箇所 


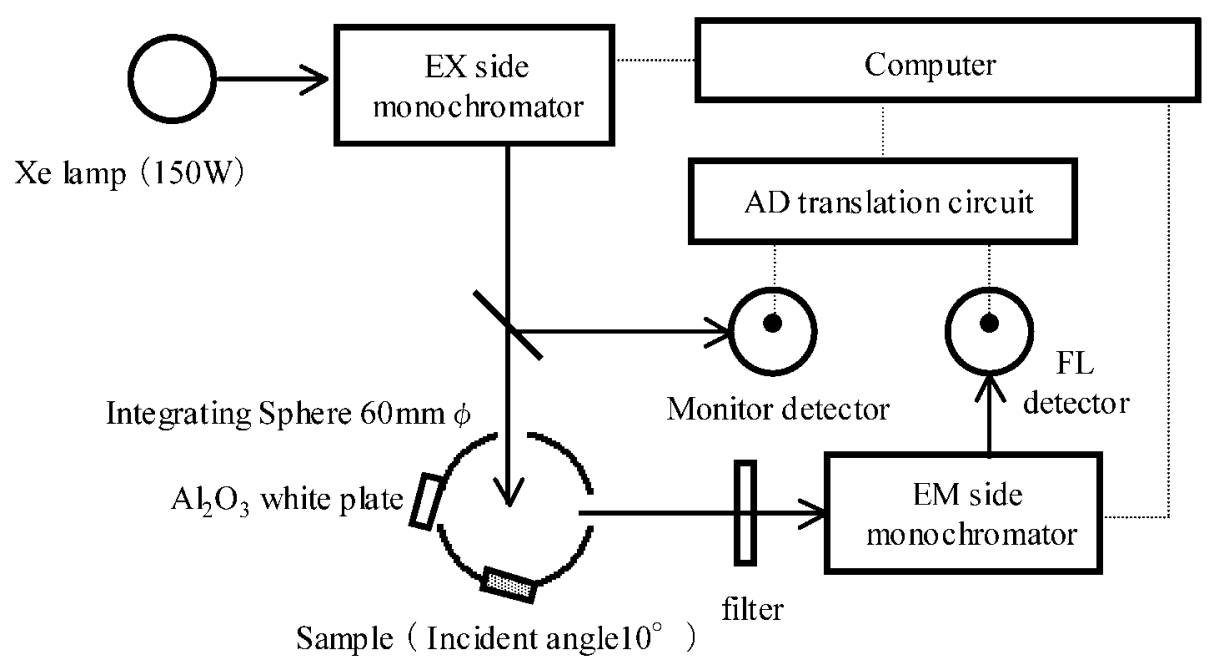

Fig. 1 A schematic diagram of an F-7000 fluorescence spectrophotometer with an integrating sphere

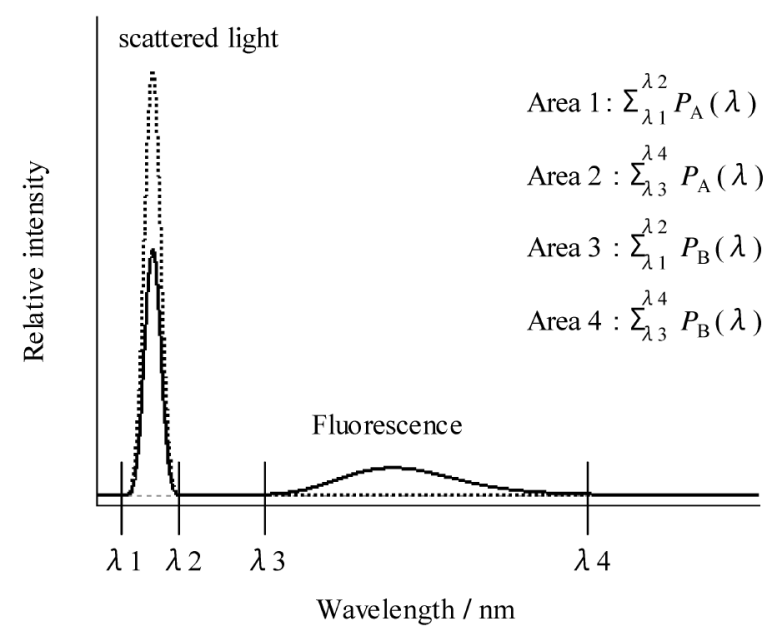

Fig. 2 Parameters used for the present correction method for quantum yield determination

$P_{\mathrm{A}}(\lambda): \mathrm{Al}_{2} \mathrm{O}_{3}$ baseline, dotted line ; $P_{\mathrm{B}}(\lambda)$ : sample, solid line

の開口部 $(\phi 16 \mathrm{~mm})$ を有し，うち 2 箇所は，入射光用開 口部と出射光開口部である. 入射光開口部の対面の開口部 は試料設置箇所である. 合成石英製のセル（高さ $40 \mathrm{~mm} \times$ 幅 $24 \mathrm{~mm} \times$ 奥行 $3 \mathrm{~mm}$ ）に粉末蛍光体試料を約 $1.5 \mathrm{~cm}^{3}$ 封 入して設置した．測定に用いていない開口部は, 酸化アル ミニウム製の副白板で開口部を覆っている．試料設置箇所 は励起光に対して入射角 $10^{\circ}$ となるように傾斜させた構造 である。

\section{$2 \cdot 2$ 量子収率測定方法の原理}

固体試料の蛍光量子収率の演算は, Fig. 2 に示す基準と 試料の 2 つの測定結果から算出する.

まず，基準としてセルに充填した酸化アルミニウム粉末 を測定する．酸化アルミニウム粉末の吸収については, 反
射率が值付けされたスペクトラロン標準白板にて補正し た. 基準の測定 $P_{\mathrm{A}}(\lambda)$ により, 試料に照射される励起光量 が測定される. Fig. 2 中の Area1 は, 試料に照射された励 起光量に相当する散乱光である. Area2 は, 積分球内面材 料に用いている硫酸バリウムや光学系の特性により生じる バックグラウンドの蛍光である.

同様に，セルに充填した試料粉末を測定する．試料の測 定 $P_{\mathrm{B}}(\lambda)$ により, 励起光の吸収と放出された蛍光が測定さ れる. Area3 は, 試料に吸収されずに残った散乱光, Area4 は, 試料からの蛍光を示す.

これらの測定結果を元に, 試料の吸収量と蛍光量を算出 し, 蛍光量子収率を演算する。蛍光量子収率の演算は, 吸 収領域と蛍光領域に分けて算出した結果を用いる。

試料の励起光の吸収量 $F_{\mathrm{abs}}$ は, 式 $(1)$ より吸収領域の散 乱光強度にて算出する。吸収量 $F_{\mathrm{abs}}$ は，基準を用いた散乱 光量と試料の散乱光量の差となる.

次に試料の蛍光量は, 試料測定の蛍光強度と基準の蛍光 強度の差となる。 ここで, 基準の蛍光強度は, バックグラ ウンド $F_{\mathrm{bkg}}$ と称し式 $(2)$ より算出する. バックグラウン ド $F_{\mathrm{bkg}}$ は, 散乱光量に依存するので, 試料測定の際におけ る散乱光量のバックグラウンドに換算するため, Area3 を Area1 で割った係数を Area2に掛け合わせる．試料測定の 蛍光強度と式 ( 2 ) より算出したバックグラウンド強度よ $り$, 試料の蛍光量 $F_{\mathrm{fl}}$ を求める式 $(3)$.

上記算出結果を基に, 蛍光量子収率 $\phi_{1}$ は式 (4) によっ て算出される.

$$
\begin{aligned}
& \text { 吸収量 } \quad F_{\mathrm{abs}}=\sum_{\lambda 1}^{\lambda 2} P_{\mathrm{A}}(\lambda)-\sum_{\lambda 1}^{\lambda 2} P_{\mathrm{B}}(\lambda) \\
& \text { バックグラウンド } \quad F_{\mathrm{bkg}}=\frac{\sum_{\lambda 1}^{\lambda 2} P_{\mathrm{B}}(\lambda)}{\sum_{\lambda 1}^{\lambda 2} P_{\mathrm{A}}(\lambda)} \times \sum_{\lambda 3}^{\lambda 4} P_{\mathrm{A}}(\lambda)
\end{aligned}
$$




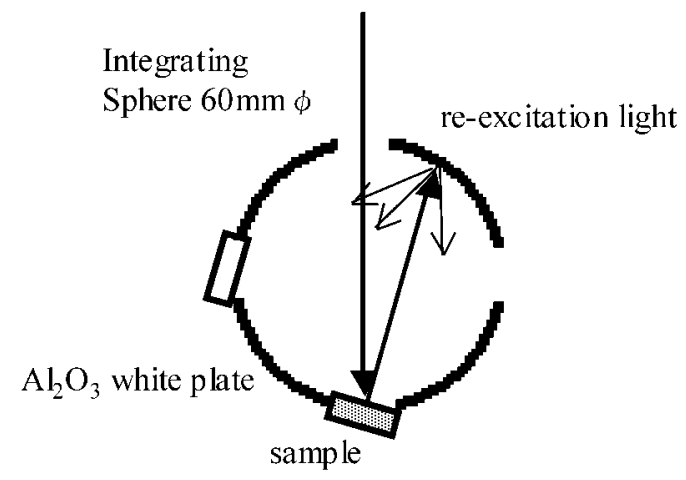

(a) Normal

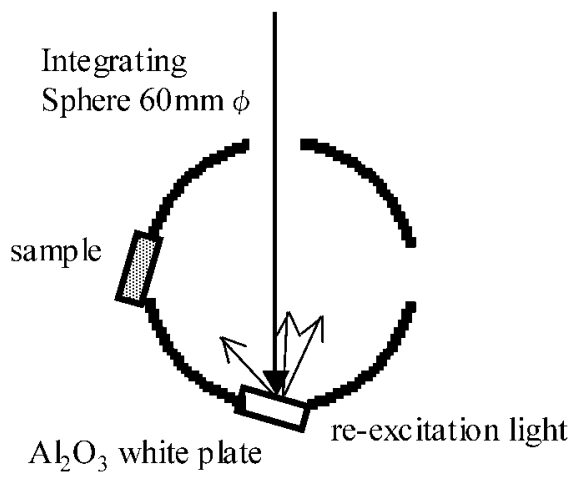

(b) Re-excitation

Fig. 3 The concept used for correcting a re-excited fluorescence

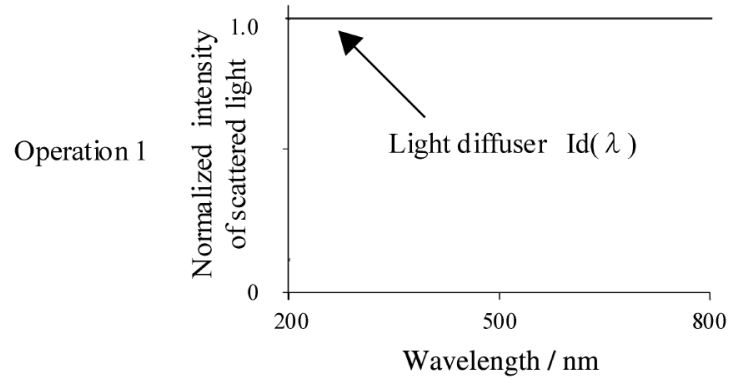

Operation 2

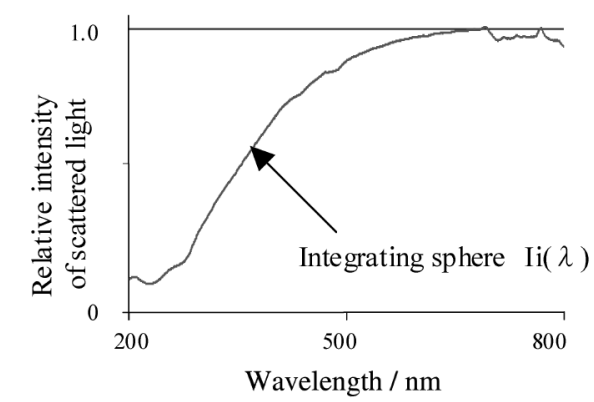

Operation 3

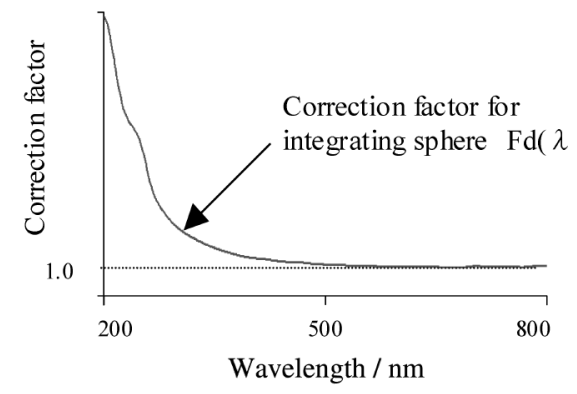

Fig. 4 The procedure for correcting a wavelength characteristics over the range between 200 and $800 \mathrm{~nm}$

$$
\text { 蛍光量 } F_{\mathrm{fl}}=\sum_{\lambda 3}^{\lambda 4} P_{\mathrm{B}}(\lambda)-F_{\mathrm{bkg}}
$$

蛍光量子収率 $\phi_{1}=\frac{F_{\mathrm{fl}}}{F_{\mathrm{abs}}}$

試料によっては, Area3 に相当する試料に吸収されなか った散乱光が積分球の内壁より拡散反射することで, 試料
の再励起が生じる，再励起により，実際よりも高い蛍光量 子収率が算出されることがある。この再励起による影響 は, Fig. 3 に示すように, 試料設置位置を励起光が直接入 射されない位置に変更し，再励起に相当する量子収率を測 定することで除く．酸化アルミニウム副白板に照射された 励起光は拡散反射し, 拡散光によって試料を励起する条件 が再現される.この試料設置位置で測定され, 式 (1) から 式 (4) にて算出された蛍光量子収率を $\phi_{2}$ とすると, 再励 起相当分は, 式 ( 5 ) で計算され, 再励起の影響を補正した 蛍光量子収率は式 (6) となる。

再励起による蛍光量子収率相当分

$$
\phi_{\mathrm{re}}=\frac{\sum_{\lambda 1}^{\lambda 2} P_{\mathrm{B}}(\lambda)}{\sum_{\lambda 1}^{\lambda 2} P_{\mathrm{A}}(\lambda)} \times \phi_{2}
$$

再励起の影響を補正した蛍光量子収率

$$
\phi_{0}=\phi_{1}-\phi_{\mathrm{re}}
$$

\section{3 結果及び考察}

\section{$3 \cdot 1$ 積分球の波長特性の補正}

$3 \cdot 1 \cdot 1$ 積分球の補正係数の取得 副標準光源による 積分球の補正方法に代わり分光蛍光光度計の励起光源であ るキセノンランプを使用する方法を検討した.

本方式の手順を Fig. 4 に示す. $10 \mathrm{~mm}$ 角セル型の光拡散 素子を Fig. 5 の試料位置に設置して, 積分球が無い状態で 分光特性 $I d(\lambda)$ を分光蛍光光度計により取得する. 光拡散 素子は，合成石英でできており，励起光源から照射される 光を一様に拡散させ, 蛍光側の検出器に光を導く役割をも つ. 測定は, 励起側分光器と蛍光側分光器を同時に走査し 同一の波長を測定する同期スペクトルモードにて実施し た.ここで，得られた分光特性 $I d(\lambda)$ を 1.0 となるように 規格化して基準とする（Fig. 4 手順 1). 次に, Fig. 5 に示 


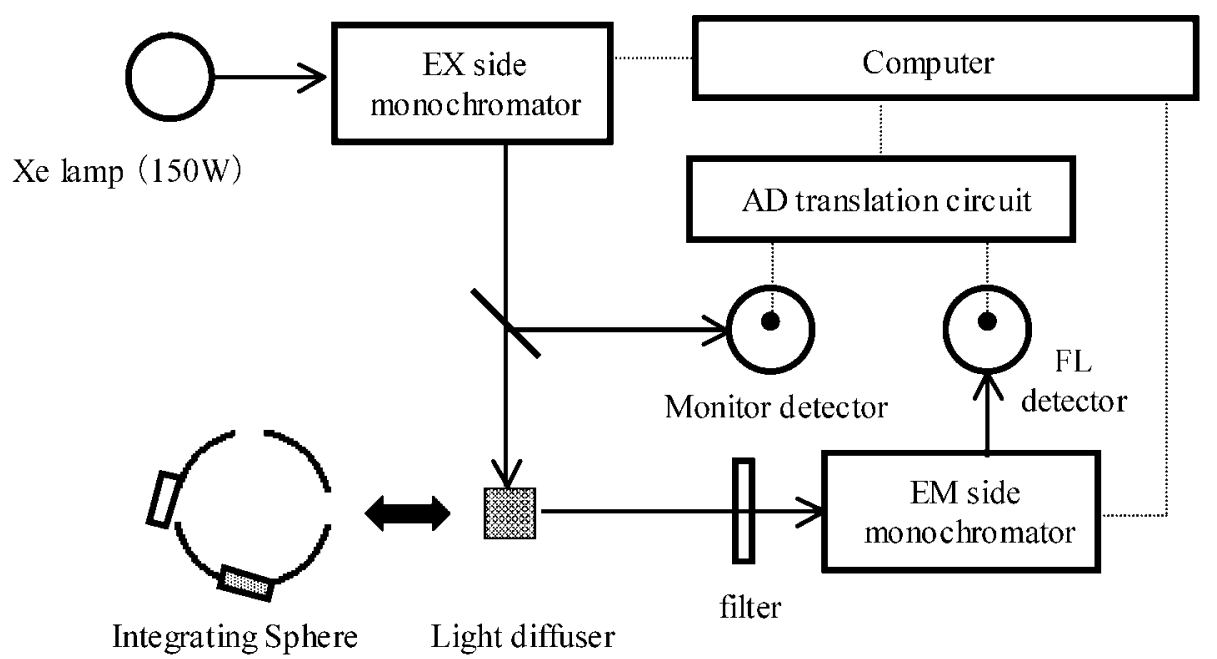

Fig. 5 A schematic diagram of an F-7000 fluorescence spectrophotometer with an integrating sphere for correcting the spectrum of the scattered light

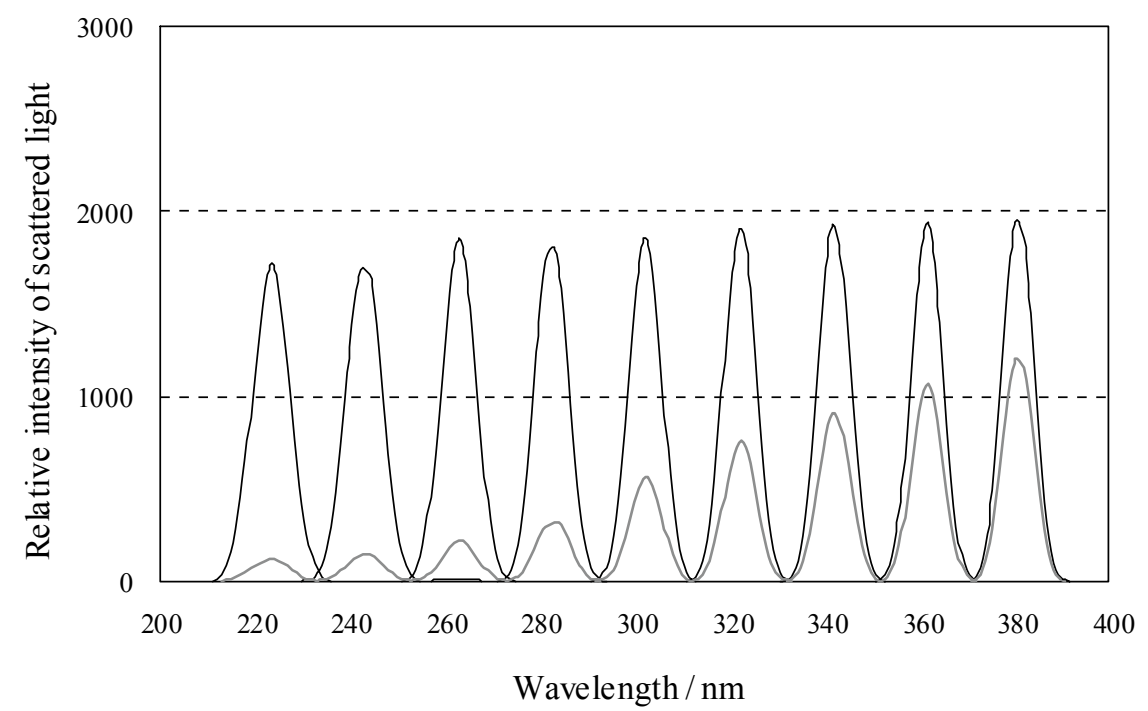

Fig. 6 Uncorrected and corrected Spectra of 220, 240, 260, 280, 300, 340, 360, or $400 \mathrm{~nm}$ scattered light by the present method without correction, dotted line ; with correction, solid line

すように，試料設置位置を積分球に変更する，積分球が無 い状態の分光特性 $I d(\lambda)$ と同じ条件で, $I d(\lambda)$ を基準とした 積分球の波長特性 $I i(\lambda)$ を取得する (Fig. 4 手順 2). 積分 球が無い状態の分光特性 $I d(\lambda)$ と積分球の波長特性 $I i(\lambda)$ の結果より式 $(7)$ にてスペクトル間演算を行い, 補正係 数 $F d(\lambda)$ を算出する (Fig. 4 手順 3).

$$
F d(\lambda)=\frac{I d(\lambda)}{I i(\lambda)}
$$

キセノンランプは, 波長 $200 〜 800 \mathrm{~nm}$ の幅広い波長範 囲で発光するので補正範囲の制限を受けない特長がある.
に塗布されている $\mathrm{BaSO}_{4}$ の影響で，紫外域で反射率が低下 し波長特性の要因となる。そこで，まず紫外域での補正精 度の検証を行った.

補正の確認には, 酸化アルミニウム粉末の散乱光強度を 波長ごとに取得し, 積分球の補正係数を測定結果に乗じて 得られた補正スペクトルにて確認した。 励起波長は, 波長 220 ～ $380 \mathrm{~nm}$ まで $20 \mathrm{~nm}$ ごとに変化させた.

補正結果を Fig. 6 に示す. 補正前の散乱光のスペクトル は, 積分球内面の $\mathrm{BaSO}_{4}$ の影響で短波長になるにつれて強 度が低下している，補正を実施することで，ほぼ一定の散 乱光強度となった．波長 $220 \mathrm{~nm}$, 波長 $240 \mathrm{~nm}$ における補 正後の散乱光のピーク強度は, 他の波長と比較して若干低 い值であった，蛍光量子収率測定の際は，散乱光領域の信 
号強度の総和より励起光量と吸収量を算出するので, 積分 球の補正後における散乱光の信号強度の総和を比較した. それぞれの励起波長ごとに散乱光強度の総和から相対標準 偏差を算出したところ $1.4 \%$ であり, 本補正法を用いるこ とで，紫外域でも十分補正が実施されていることが明らか となった。

次に, 測定波長全域の補正の検討を行った。検討には, 補正取得時と同じ条件で酸化アルミニウム粉末を用いて補 正同期スペクトルを取得した（Fig. 7)。得られた補正同期 スペクトルは, 波長 $200 \sim 400 \mathrm{~nm}$, 波長 $400 \sim 600 \mathrm{~nm}$, 波

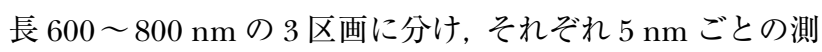
定值から相対標準偏差を算出することで, 測定波長全域の 補正を検討した，算出された相対標準偏差は，波長 200 $400 \mathrm{~nm}$, 波長 $400 \sim 600 \mathrm{~nm}$, 波長 $600 \sim 800 \mathrm{~nm}$ の 3 区画

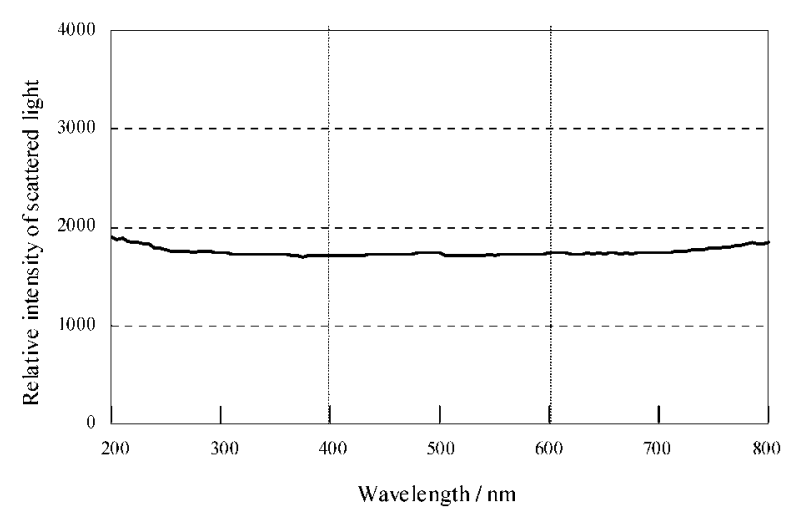

Fig. 7 A corrected synchronized spectrum of scattered light over the range between 200 and $800 \mathrm{~nm}$ by the present method
において，それぞれ，3.1，0.6，2.1\% であった．波長 200 〜 $800 \mathrm{~nm}$ の測定波長全域に渡る相対標準偏差は, $2.5 \%$ で あった. 補正係数が大きい波長 $200 \sim 400 \mathrm{~nm}$ の紫外域で, 相対標準偏差が若干大きくなった．また，積分球の内面材 料である $\mathrm{BaSO}_{4}$ の反射率が高く，補正係数が小さい波長 $400 \sim 800 \mathrm{~nm}$ の相対標準偏差は比較的小さな值となった.

本補正方法の補正誤差は数\% 程度であり, 従来用いら れていた副標準光源による方法では難しかった紫外域の積 分球の補正が可能となった，結果として，波長 $200 〜 800$ $\mathrm{nm}$ の幅広い測定範囲で積分球の補正が可能であり, 一般 の分光蛍光光度計に容易に適用することが可能であること が明らかになった.

\section{$3 \cdot 2$ 標準蛍光体の蛍光量子収率測定}

蛍光体の量子収率の標準としては, NBS（現 NIST：米国 標準技術研究所) 製の標準蛍光体が知られている(1)7) 9). し かしながら, NBS 標準蛍光体は現在入手不可能であるの で, NBS-1027 と同一組成の $\mathrm{MgWO}_{4}$ (高純度化学研究所) を測定した。

励起波長 $254 \mathrm{~nm}$ における蛍光量子収率を測定し，大久 保らの報告值と比較した. 測定の際, 測定再現性及び試料 充填のばらつきを評価するため, 試料の詰め替えを含めて 5 回の測定を行った。なお，すべての測定においてスペク トル補正及び再励起の補正を実施している．励起波長の高 次光が蛍光スペクトルと重複するので, カットフィルタ （UV29）を用いて $290 \mathrm{~nm}$ 以下をカットして測定した.

$\mathrm{MgWO}_{4}$ の散乱光領域と蛍光領域におけるスペクトルを Fig. 8 に示す. 本法で得られた蛍光量子収率は 0.80 とな (a) Scattered light

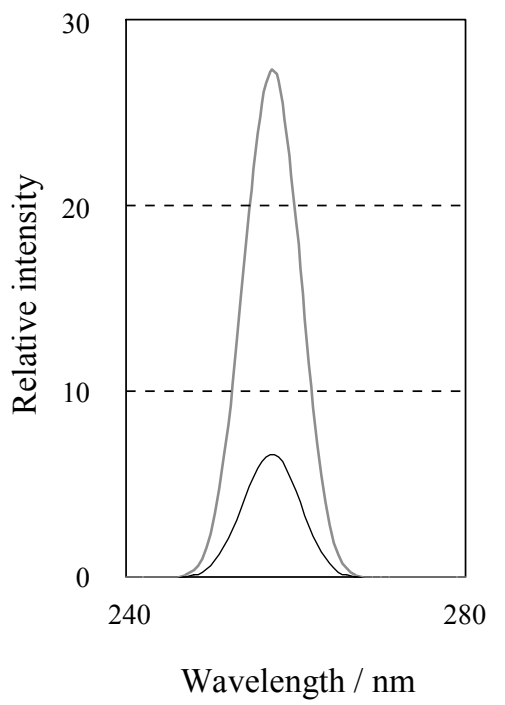

(b) Fluorescence

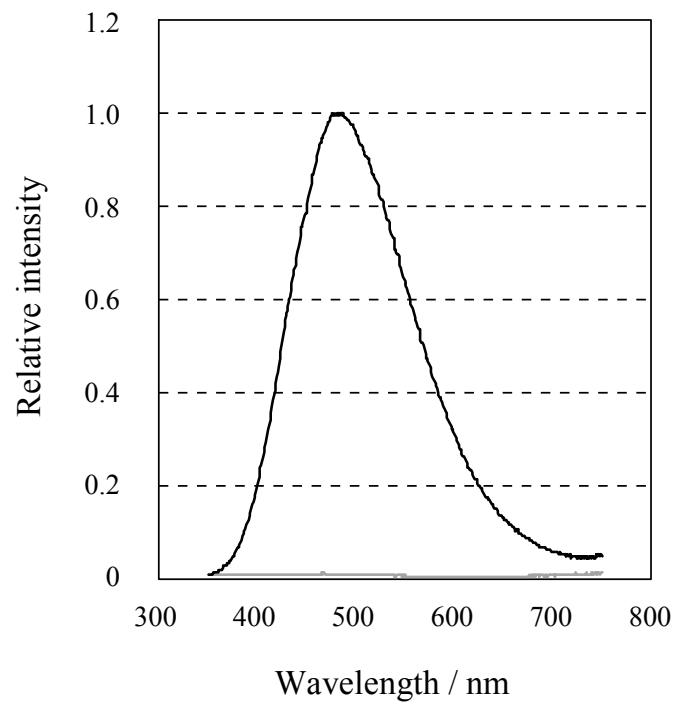

Fig. 8 Fluorescent spectrum of $\mathrm{MgWO}_{4}$ upon excitation at $254 \mathrm{~nm}$ for the quantum yield measurement

$\mathrm{Al}_{2} \mathrm{O}_{3}$ baseline, dotted line ; $\mathrm{MgWO}_{4}$, solid line 
(a) Scattered light

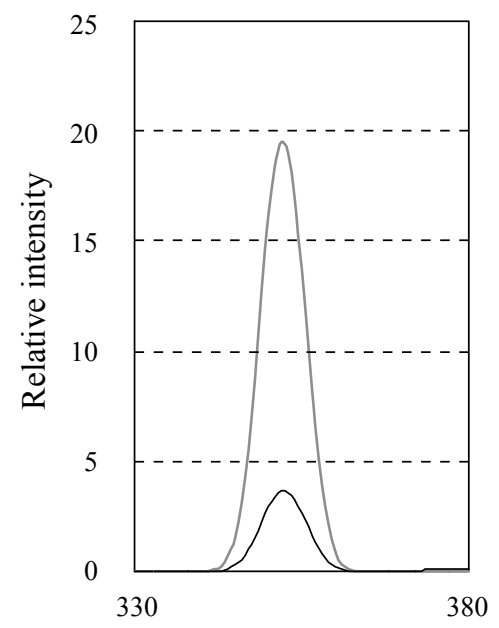

Wavelength / nm (b) Fluorescence

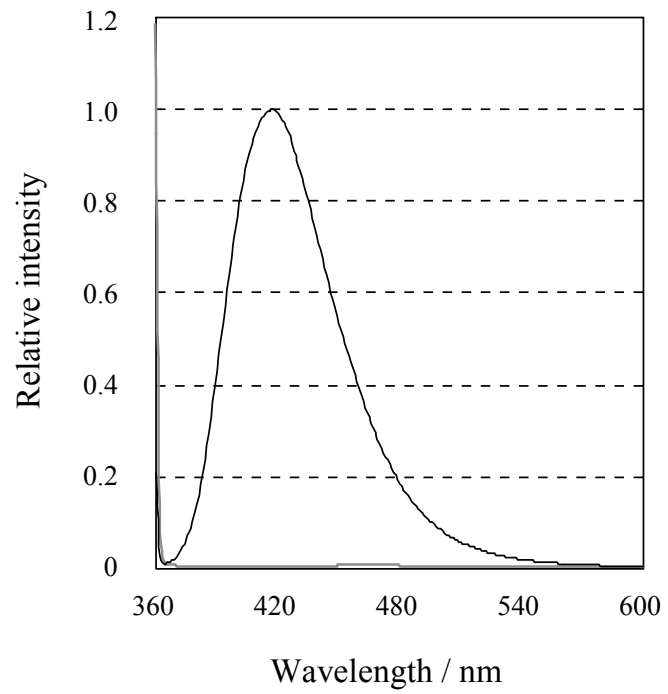

Fig. 9 Fluorescent spectrum of sodium salicylate upon excitation at $350 \mathrm{~nm}$ for the quantum yield measurement

$\mathrm{Al}_{2} \mathrm{O}_{3}$ baseline, dotted line ; salicylate, solid line

Table 1 Quantum yields of sodium salicylate measured by the present method

\begin{tabular}{ccc}
\hline EX wavelength/nm & Quantum yield & RSD, \% \\
\hline 250 & $0.49 \pm 0.00_{4}$ & 0.8 \\
270 & $0.51 \pm 0.00_{3}$ & 0.6 \\
290 & $0.52 \pm 0.00_{3}$ & 0.6 \\
310 & $0.50 \pm 0.00_{2}$ & 0.4 \\
330 & $0.50 \pm 0.00_{2}$ & 0.5 \\
350 & $0.44 \pm 0.00_{2}$ & 0.4 \\
\hline
\end{tabular}

り，5回測定の相対標準偏差は $0.6 \%$ であった。試料の詰 め替えを行っても再現性の高い結果が得られている. 蛍光 量子収率の測定值については, 同一試料での測定值の比較 ではないが, 同一組成の比較としては装置構成が異なるこ とを考慮しても, 大久保らの報告值と良い一致が得られて いると考えられる.このことから， $3 \cdot 1$ 項に示した励起光 源を用いたスペクトル補正は, 実際の量子収率測定におい ても有効であることが分かった。

\section{$3 \cdot 3$ サリチル酸ナトリウムの量子収率測定}

紫外～真空紫外領域の可視光変換材料として真空紫外用 検出器（シンチレータ）に用いられているサリチル酸ナト リウムの蛍光量子収率を測定した。

サリチル酸ナトリウムにおける散乱光領域と蛍光領域に おけるスペクトルを Fig. 9 に示す. 励起波長 $350 \mathrm{~nm}$ にお けるサリチル酸ナトリウムの蛍光量子収率は 0.44 となり, 5 回測定（試料の詰め替えを含む）の相対標準偏差は $0.4 \%$ であった。
サリチル酸ナトリウムを用いて, 励起波長 250 ～350 nm において, 励起波長 $20 \mathrm{~nm}$ ごとの蛍光量子収率を測定した (Table 1).W. Slavin らは, 紫外領域におけるサリチル酸 ナトリウムの励起波長ごとの相対的な蛍光量子収率は, ほ ぼ一定であると報告している ${ }^{10)}$ 。併せて, サリチル酸ナト リウムの波長 250〜350 nm における励起スペクトルを取 得し, 励起波長 $20 \mathrm{~nm}$ ごとの相対強度を蛍光量子収率の測 定結果と共にプロットした（Fig. 10）。W. Slavin らの報告 と同様に，波長 250 ～ $330 \mathrm{~nm}$ までは，ほぼ一定の蛍光量 子収率が得られ, 波長 $350 \mathrm{~nm}$ で蛍光量子収率の低下が見 られた. 各励起波長における 5 回測定（試料の詰め替えを 含む）の相対標準偏差は $0.8 \%$ 以内であった．また，励起 波長ごとの蛍光量子収率の測定結果は, 励起スペクトルと も一致しており，サリチル酸ナトリウムの測定結果から も，スペクトル補正方法及び本測定系の妥当性が確認され た.

\section{4 結 論}

蛍光量子収率を測定するために，分光蛍光光度計に搭載 されている励起光源を用いた積分球の波長特性の補正方法 を検討した，検討した積分球の補正方法は，波長 $200 〜 800$ $\mathrm{nm}$ までの幅広い波長域に対応したスペクトル補正を可能 する.この補正方法を用いて，量子収率の測定を行ったと ころ, 量子収率の報告值のある $\mathrm{MgWO}_{4}$ 及びサリチル酸ナ トリウムの測定において報告值とほぼ一致した結果が得ら れスペクトル補正方法及び蛍光量子収率における測定系の 妥当性が示された. 


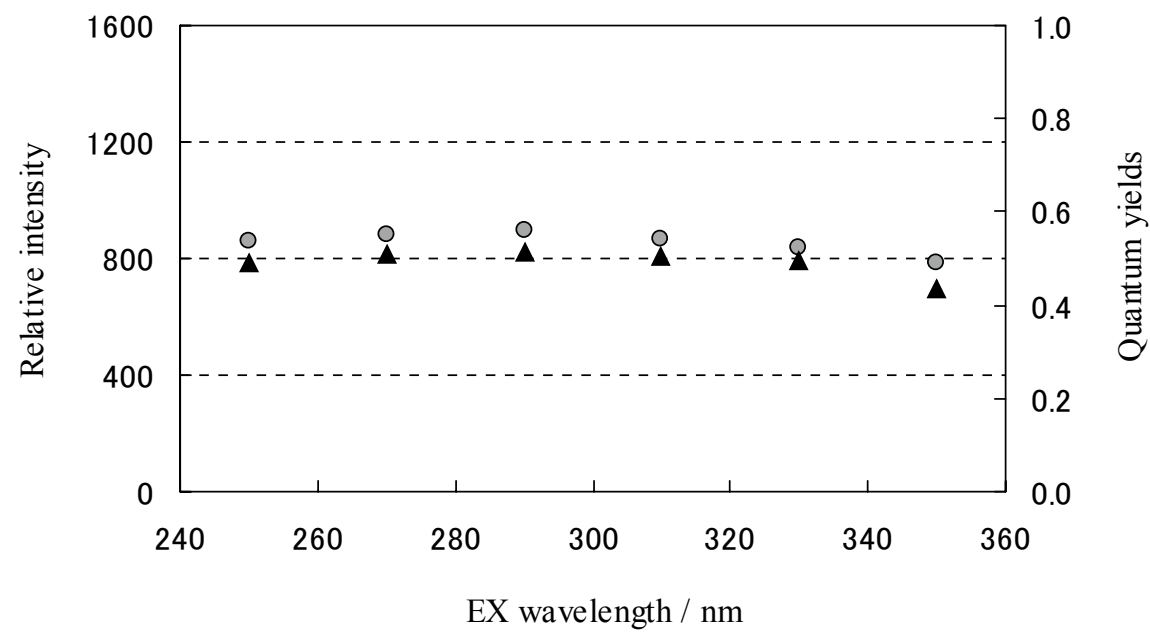

Fig. 10 Measurement of quantum yields (triangle) and relative fluorescent intensity (circle) by changing excitation wavelength

\section{文献}

1) 大久保和明, 重田照明: J. Illum. Engng. Inst. Jpn, 83-2, 87 (1999).

2) N. C. Greenham, I. D. W. Samuel, G. R. Hayes, R. T. Phillips, Y. A. R. R. Kessener, S. C. Moratti, A. B. Holmes, R. H. Friend: Chem. Phys. Lett., 241, 89 (1995).

3) L.-O. Pållson, A. P. Monkman : Adv. Mater., 14, 757 (2002).

4) 田村善蔵, 太幡利一, 保田和雄 : “けい光分析”, p.
81 (1974), (講談社サイエンティフィック).

5) 木下和彦, 御橋廣眞: “蛍光測定”, p. 63 (1983), (学 会出版センター).

6) 西川泰治, 平木敬三 : “蛍光・りん光分析法”, p. 70 (1984), (共立出版).

7) 成田和夫: J. Illum. Engng. Inst.Jpn, 69-2, 65 (1985).

8) A. Bril, W. Hoekestra: Philips Res. Rep., 16, 356 (1961).

9) C. F. Shelton: NBS Technical Note, 417, 1 (1968).

10) W. Slavin, R. W. Mooney, D. T. Palumbo : J. Opt. Soc. Am, 51, 93 (1961).

\title{
A Simple Correction Method for Determination of
}

Absolute Fluorescence Quantum Yields of Solid Samples with a

\section{Conventional Fluorescence Spectrophotometer}

\author{
Jun Horigome $^{1}$, Takayuki WAkUI ${ }^{1}$ and Toshihiro ShIRASAKI ${ }^{1}$ \\ ${ }^{1}$ Hitachi High-Technologies Corporation, 11-1, Ishikawa-cho, Hitachinaka-shi, Ibaraki 312-0057
}

(Received 7 November 2008, Accepted 19 March 2009)

The absolute fluorescence quantum yield of a solid sample was measured by using a fluorescence spectrophotometer equipped with an integrating sphere. However, there were difficulties in making a spectrum correction of the integrating sphere. To solve this problem, we developed a simple method for determining its wavelength characteristics, by using the ratio of the diffuser to the integrating sphere. They were measured by combining both scan data with corrected excitation light. As a result, we were able to measure the corrected spectrum over a wide wavelength range of $200 \mathrm{~nm}$ to $800 \mathrm{~nm}$. The experimental value of the fluorescence quantum yield of $\mathrm{MgWO}_{4}$ was 0.80 (RSD $0.6 \%$ ) with the present method, which is a good agreement with a reported value $(0.81)$.

Keywords : fluorescence spectrophotometer ; quantum yield ; integrating sphere ; solid phosphor. 